\title{
Initial experience for first pass cardiac perfusion with iterative reconstruction in patients
}

\author{
Laura lacuzio ${ }^{1 *}$, Stéphane Rusek¹, Solenne Tutenuit ${ }^{1}$, Michael O Zenge², Christoph Forman², Michaela Schmidt ${ }^{2}$, \\ Karen Mkhitaryan ${ }^{2}$
}

From 18th Annual SCMR Scientific Sessions

Nice, France. 4-7 February 2015

\section{Background}

MR stress perfusion is a non-invasive, reliable and safe test for ischemic heart disease [1]. Recent publications reported sensitivity and specificity of $89 \%$ and $80 \%$ respectively [2]. Image quality improvements seem to be essential for improving the predictive value of the method. This leads to the dilemma of finding a compromise between high spatial resolution and sufficient SNR. Lately iterative reconstruction demonstrated great promise in improving SNR [3]. The aim of the current study was to compare cardiac perfusion in 24 patients reconstructed with product and a novel prototype iterative reconstruction.

\section{Methods}

24 patients (mean age $62 \pm 15$ ) were examined on a $1.5 \mathrm{~T}$ clinical MR scanner (MAGNETOM Aera, Siemens AG, Erlangen, Germany) using a saturation prepared TFL product sequence with the following parameters: $\mathrm{TR} / \mathrm{TE}=331 / 1.4 \mathrm{~ms} ;$ Flip angle $=12^{\circ} ; \mathrm{BW}=668 \mathrm{~Hz} / \mathrm{Px}$; Voxel size $=0.8 \times 0.8 \times 10.0 \mathrm{~mm}$ (inplane interpolated); FOV $=290 \mathrm{~mm} 2$; Matrix $=170 \times 192 ;$ Slice thickness $=10 \mathrm{~mm}$; Acceleration $=2$; Inversion time $=180 \mathrm{~ms}$; Phase oversampling $=60 \%$; Motion correction.

Pharmacological stress was applied using Adenosine (Adenoscan ${ }^{\circledR}$, Sanofi-Synthelabo). Gadolinium-based contrast agent (Magnevist, Bayer Schering Pharma) was

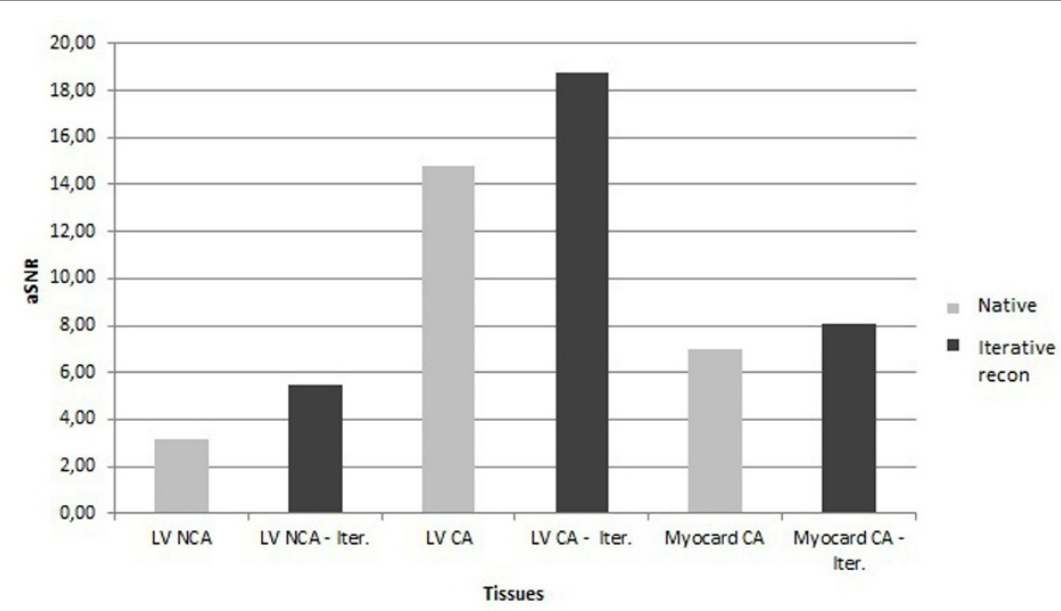

Figure 1 aSNR in different tissues (myocardium and left ventricle cavity without (NCA) and with Contrast Agent (CA)). Product vs. iterative reconstruction.

${ }^{1}$ MR service, Centre Cardio Thoracique Monaco, Monte Carlo, Monaco

Full list of author information is available at the end of the article

(c) 2015 lacuzio et al; licensee BioMed Central Ltd. This is an Open Access article distributed under the terms of the Creative Commons Attribution License (http://creativecommons.org/licenses/by/4.0), which permits unrestricted use, distribution, and reproduction in any medium, provided the original work is properly cited. The Creative Commons Public Domain Dedication waiver (http:// creativecommons.org/publicdomain/zero/1.0/) applies to the data made available in this article, unless otherwise stated. 


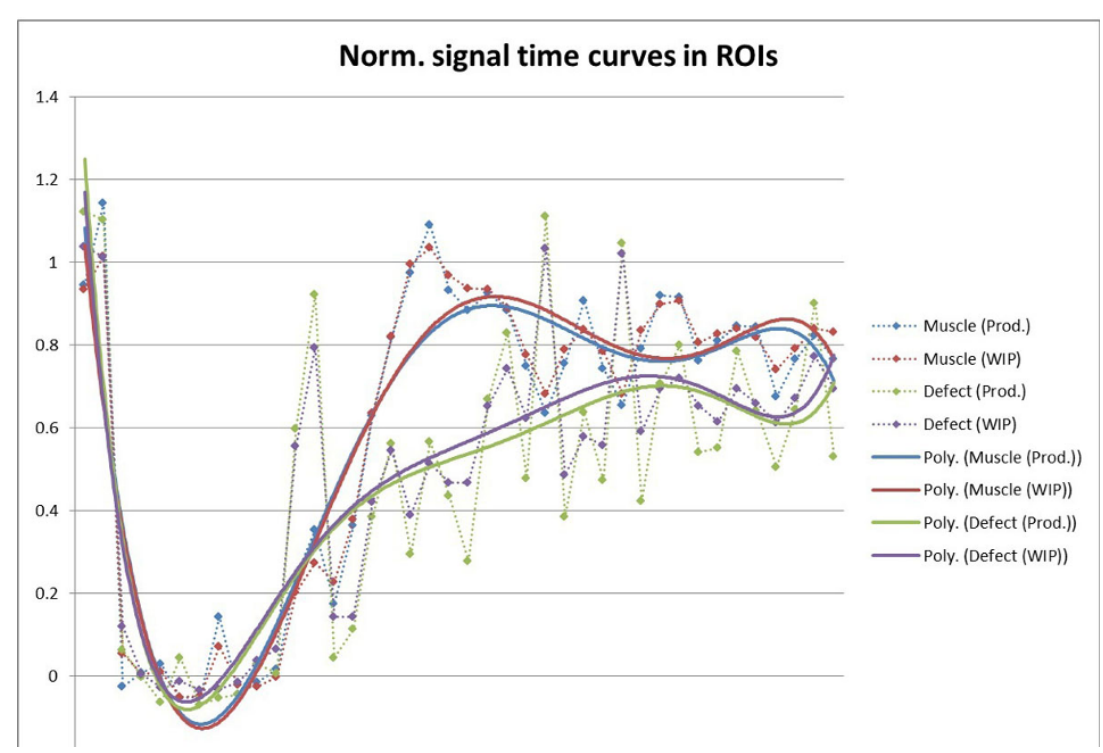

Figure 2 Example of signal uptake in selected ROls with iterative (WIP) and reference (Prod.) reconstruction.

administered and MRI was performed over 4 slices in short-axis orientation in breath-hold.

Image reconstruction was run twice online at the scanner: 1 ) with the product image reconstruction and 2) a regularized SENSE-type iterative reconstruction [4] (60 iterations, regularization 0.008). Apparent signal-to-noise ratios (aSNR) [5] were calculated in multiple regions of interest in the left ventricle and myocardium. In addition, normalized semi-quantitative upslope curves were qualitatively compared for both methods.

\section{Results}

The quantitative results of aSNR in Figure 1 confirm the overall improvement of the image quality over all patients. Temporal filtering introduced by the regularized reconstruction seems to be negligible as the semi-quantitative upslope curves showed generally good concordance. Figure 2.

\section{Conclusions}

Iterative image reconstruction shows great image quality improvements over the conventional reconstruction. In the future, SNR improvements can be invested in increasing the spatial resolution which might help to better avoid e.g. the dark rim artifact.

\section{Funding}

None.

\section{Authors' details}

${ }^{1}$ MR service, Centre Cardio Thoracique Monaco, Monte Carlo, Monaco.

${ }^{2}$ Siemens AG, Erlangen, Germany.
Published: 3 February 2015

\section{References}

1. Nandalur KR, et al: J Am Coll Cardiol 2007, 50:1343-53.

2. Hamon M, et al: I Cardiovasc Magn Reson 2010, 12:29.

3. Adluru G, et al: MRM 2007, 57:1027-36.

4. Liu J, et al: ISMRM 2012, 178

5. Chung, et al: IEEE CIS 2004, 365-60.

\section{doi:10.1186/1532-429X-17-S1-Q109}

Cite this article as: lacuzio et al: Initial experience for first pass cardiac perfusion with iterative reconstruction in patients. Journal of Cardiovascular Magnetic Resonance 2015 17(Suppl 1):Q109.
Submit your next manuscript to BioMed Central and take full advantage of:

- Convenient online submission

- Thorough peer review

- No space constraints or color figure charges

- Immediate publication on acceptance

- Inclusion in PubMed, CAS, Scopus and Google Scholar

- Research which is freely available for redistribution

Submit your manuscript at www.biomedcentral.com/submit
C Biomed Central 